Article

\title{
Effects of 5 Aza 2' Deoxycytidine on Proliferation and Differentiation of Embryonic Chick Caudal Region Chondrocytes in Culture
}

\author{
Samina Hyder Haq \\ Department of Biochemistry, College of Science, King Saud University, Riyadh P.O. 11362, Saudi Arabia; \\ shaq@ksu.ed.sa; Tel.: +96611-8052697
}

\begin{abstract}
DNA methylation is one of the epigenetic mechanisms which have been implicated in cellular differentiation, ageing and disease development. The effect of hypomethylating drug 5-aza-2' deoxycytidine (5-aza dC) on the biosynthetic profile of caudal region chondrocytes from chick sternum was studied in detail. The chondrocytes in culture were treated with varying doses of 5-aza dC for $48 \mathrm{~h}$ and maintained subsequently without the treatment and harvested at selected time points for analysis of growth and differentiation status. $15 \mu \mathrm{g} / \mathrm{ml}$ of 5 -aza dC showed optimum Concentration at which there was a significant increase in DNA synthesis and RNA synthesis as per cell basis. There was also a significant increase in total protein synthesis and collagen synthesis as per cell basis at this concentration. This optimal concentration also showed to up regulate the gene expression of Type $\mathrm{X}$ collagen and alkaline phosphatase, which are the marker of hypertrophic chondrocyte expression. These results further support the notion that methylation is the major epigenetic factor controlling the differentiation and maturation of chondrocytes.
\end{abstract}

Keywords: ALP (alkaline phosphatase); OA (osteoarthritis); 5-aza dC (5-aza-2'deoxycytidine); epigenetics

\section{Introduction}

Skeletogenesis in vertebrate is characterized by a precise temporal and spatial coordination of growth and differentiation with concomitant reorganization of preexisting structural elements consist of primarily the extracellular matrix (ECM).This is particularly manifested in the growth of long bone called endochondral ossification (EO), where chondrocytes pass through discrete stages of proliferation, maturation, and hypertrophy and eventually calcification. The exact molecular mechanism governing the articular cartilage remains oblivious in skeletal biology. This process can be observed in cephalic region of embryonic chick sternum, where the morphogenetic changes in the matrix may be followed by both morphologically and biochemically [1-3]. For example the chick sterna prior to day 16/17 are mainly composed of closely packed small rounded chondrocytes. These cells usually synthesize predominantly Collagen type II, type IX (and type XI collagens [4, 5]. Starting from day 17 of chick development distinct morphological changes occurs in the chondrocyte morphology in the cephalic region of chick sternum. The chondrocytes become hydrated and markedly increase in size due to cytoplasmic and nuclear swelling. In this hypertrophic stage of the chondrocyte, the cells remain biochemically active and secrete Type $\mathrm{X}$ collagen which is considered to be the biochemical marker of hypertrophic chondrocytes [6]. As hypertrophy progresses, type $X$ collagen synthesis increases to about $45 \%$ of total collagen produced [3]. The marked increase in 
type $\mathrm{X}$ collagen is accompanied by a relative decrease in other collagens [7] suggesting the change in the extracellular matrix. While in the caudal region of chick sterna the chondrocytes remain rounded and maintains their resting cell phenotype. This is also true in superficial articular cartilage where the chondrocytes remain in their rounded resting state morphology secreting basically the cartilage specific collagen (Type II) as the main biosynthetic product as well as cartilage specific proteoglycans (PGs) which helps in the maintenance of normal articular cartilage functions in the healthy individuals. However this balance is disrupted in osteoarthritis (OA) where there is extensive breakdown of extracellular matrix by aggregenase and collagenases.

During OA increasing number of chondrocytes from articular cartilage undergoes a remarkable phenotypic modulation turning them into hypertrophic chondrocytes as described above. These hypertrophic cells secrete type $X$ collagen and alkaline phosphatase enzyme $[8,9]$ as well as different cartilage degrading proteases which results in the progression of OA. The maintaining of the normal chondrocytes as that of adult somatic cells is stabilized by epigenetic factors. This raises the possibility that the destabilization of chondrocyte morphology could be the result of change in its epigenetic status. The role of epigenetic modification controlling the chondrocyte hypertrophy is being suggested $[10,11]$ but still poorly understood.

In order to study the molecular mechanisms that control the differentiation of chondrocytes, the hypomethylating drug 5-aza-2' deoxycytidine was used in the chick sternal chondrocytes in cultures. This study aimed to find out the optimum dosage of the drug and the effective duration for the treatment of chondrocytes. The effects on the pretreatment of chondrocytes with this de-methylation drug were further investigated by keeping these cells in long term cultures and studying their gene expression.

\section{Materials and Methods}

2.1: Chondrocytes culture: About ten sterna of day $17^{\text {th }}$ chick embryos were dissected and removed from the surrounding tissues. The cephalic and Caudal (one third part of the tip region) of sterna were dissected as described by [12]. Tissues were finely diced and pre- incubated for $30 \mathrm{~min}$ at $37^{\circ} \mathrm{C}$ with Bacterial collagenase type $1 \mathrm{~A}(10 \mathrm{mg} / \mathrm{ml})$ purchased from Sigma chemical Co., Dorset U.K. and Trypsin $(0.4 \mathrm{mg} / \mathrm{ml})$ GIBCO (BRL) in minimal essential medium. The resulting supernatant containing the perichondria fibroblasts were removed and tissues were further incubated for $60 \mathrm{~min}$ under the same conditions as above. Released chondrocytes were washed three times with DMEM $+10 \%$ FCS GIBCO (BRL). Chondrocytes were cultured in $75 \mathrm{~cm}^{2}$ plastic tissue culture dishes or in multiwall tissue culture plates with the seeding density of $1 \times 10^{5} \mathrm{cells} / \mathrm{cm}^{2}$. All the cultures were incubated at $37{ }^{\circ} \mathrm{C}$ in an atmosphere of $95 \%$ air and $5 \% \mathrm{CO}_{2}$ in DMEM which was buffered with $10 \mathrm{mM}$ HEPES and $0.37 \%$ sodium bicarbonate and supplemented with $100 \mu \mathrm{g} / \mathrm{ml}$ Ascorbate, 100 units $/ \mathrm{ml}$ penicillin, $0.1 \mathrm{mg} / \mathrm{ml}$ streptomycin $100 \mu \mathrm{g} / \mathrm{ml}$ glutamine and $10 \%$ fetal calf serum (FCS). 


\section{2: Treatment of chondrocyte culture:}

One hour after plating cultures were treated in triplicates with $\quad 0,2.5,5,10,15$ and $20 \mu \mathrm{g} / \mathrm{ml}$ of 5 -aza $\mathrm{dC}$ ( purchased from Sigma chemical Co., Dorset U.K ) in the culture medium which contains DMEM $+10 \%$ FCS as described above for $48 \mathrm{~h}$. The medium was then removed and the cultures were maintained in DMEM $+10 \% \mathrm{FCS}+100 \mu \mathrm{g} / \mathrm{ml}$ ascorbate, 100 units $/ \mathrm{ml}$ penicillin, and $0.1 \mathrm{mg} / \mathrm{ml}$ streptomycin and $100 \mu \mathrm{g} / \mathrm{ml}$ glutamine. The medium was replaced after every other day throughout the culture period. Control cultures were set up as described above without the pretreatment with 5 -aza dC.

\section{3: Estimation of DNA Content:}

The DNA content of the cell pellet was determined by [13]. Cell pellet was suspended in $200 \mu l$ of fresh extraction buffer (0.01Tris- $\mathrm{HCl} \mathrm{pH}$ 7.4) and an equal volume of percholoric acid added prior to incubation at $4{ }^{\circ} \mathrm{C}$ for $30 \mathrm{~min}$. The cell pellet was centrifuged at $10,000 \mathrm{~g}$ for $10 \mathrm{~min}$, supernatant discarded and insoluble pellet hydrolyzed with $250 \mu \mathrm{l}$ of $1 \mathrm{M}$ percholoric acid at $70^{\circ} \mathrm{C}$ for $30 \mathrm{~min}$. Hydro-lysate was than cooled and $0.5 \mathrm{ml}$ of freshly prepared chromogenic reagent was added and incubated at $37^{\circ} \mathrm{C}$ overnight. The absorbance was read at $600 \mathrm{~nm}$ against a blank reagent. Calf thymus DNA standard ranging from 0.5 to $100 \mu \mathrm{g}$ were assayed with each series of sample.

\section{4: Assay of DNA synthesis}

The cells were incubated with varying concentration of 5-aza-2' deoxycytidine as described in section 2.2 for $48 \mathrm{~h}$ above and then incubated for $24 \mathrm{~h}$ in DMEM containing $0.01 \%$ transferrin and $4 \mathrm{mM}$ amethopterin in dimethyl formamide to inhibit de-nova thymidine synthesis. A pulse of [ $\left.{ }^{3} \mathrm{H}\right]$ thymidine $(5 \mu \mathrm{Ci} / \mathrm{ml})$ was introduce for $90 \mathrm{~min}$. The wells were then washed with $1.5 \mathrm{ml}$ of ice cold phosphate buffer solution (PBS) followed by overnight precipitation of the nucleic acid with $5 \%$ ice cold TCA in the presence of cold salmon sperm DNA. The precipitate were washed twice with $1.5 \mathrm{ml}$ ice cold $95 \%$ ethanol and then solubilized in $2 \mathrm{ml}$ of $0.1 \mathrm{M}$ sodium hydroxide $(\mathrm{NaOH})$. A $100 \mu$ aliquot of the solubilized precipitate was mixed with $3 \mathrm{ml}$ of scintillant and counted using a Packard Scintillation counter. Cell number was determined on a coulter counter after briefly trypsinising cells with trypsin /EDTA(0.25M) salt solution.

2.5: Assay of RNA synthesis. The cells were incubated with varying concentrations of 5-aza-2' deoxycytidine as described in Section $\mathbf{2 . 2}$ above and then incubated with [ $\left.{ }^{3} \mathrm{H}\right]$ uridine $(5 \mu \mathrm{Ci} / \mathrm{ml})$ for $24 \mathrm{~h}$ in DMEM, $10 \% \mathrm{FCS}$ and $100 \mu \mathrm{g} / \mathrm{ml}$ ascorbate/glutamine and $0.01 \%$ transferrin. The wells were then washed with $1.5 \mathrm{ml}$ of ice cold PBS followed by overnight precipitation of the nucleic acid with $5 \%$ ice cold trichloric acid ( TCA) in the presence of cold salmon sperm DNA. The precipitate were washed twice with $1.5 \mathrm{ml}$ ice cold $95 \%$ ethanol and then solubilized in $2 \mathrm{ml}$ of $0.1 \mathrm{M}$ $\mathrm{NaOH}$. A $100 \mu \mathrm{l}$ aliquot of the solubilized precipitate was mixed with $3 \mathrm{ml}$ of scintillant and counted 
using a Packard Scintillation counter. Cell number was determined on a coulter counter after briefly trypsinising cells with $0.25 \%$ trypsin / 0.25 mMEDTA.

\section{6: Hydroxyproline assay:}

Hydroxyproline assay was done by two methods as was described by [14]. The percentage of proline and hydroxyproline was also measured by amino acid analysis. Triplicate samples were used to assay hydroxyproline. The other Triplicate samples were used to measure the cell count at the end of the experiment. The Cells were maintained for 7 days prior to labeling with $1 \mu \mathrm{Ci} / \mathrm{ml}$ of $\mathrm{L}-[$ $\left.{ }^{5-}{ }^{-3} \mathrm{H}\right]$ proline in the presence of DMEM which contains $10 \% \mathrm{FCS} 50 \mu \mathrm{g} / \mathrm{ml}$ of $\beta$ APN and $100 \mu \mathrm{g} / \mathrm{ml}$ of ascorbate /glutamine for $24 \mathrm{~h}$. Proteinase inhibitors were added as described before at the end of incubation and the medium samples were then dialyzed against running water for at least $48 \mathrm{~h}$. Cell surface were washed once with PBS and scraped off in 500 $\mu$ PBS and then dialyzed against running tap water. The medium and cell layer/matrix proteins were hydrolyzed in $6 \mathrm{M} \mathrm{HCl}$ at $120^{\circ} \mathrm{C}$ overnight. The hydrolyzed were evaporated to dryness under vacuum, the residue dissolved in $1 \mathrm{ml}$ of $1 \mathrm{M} \mathrm{HCl}$ and the radioactivity present in $100 \mu \mathrm{l}$ aliquot measured on the scintillation counter. Hydrolyzed containing about 15,000dpm was loaded onto a column analysis on amino acid analyzer. The samples were eluted with a citrate buffer $\mathrm{pH} 3$.0. About $1 \mathrm{ml}$ fractions were collected and counted on scintillation counter. $\left[{ }^{3} \mathrm{H}\right]$ proline and $\left[{ }^{3} \mathrm{H}\right]$ hydroxyproline peaks obtained were used to calculate percentage hydroxylation.

\section{7: Western blotting:}

Medium proteins from control and treated chondrocyte cultures were recovered by $30 \%$ ammonium sulphate precipitation. The precipitate was dialyzed extensively against PBS buffer and mixed with $4 \mathrm{X}$ sample buffer, boiled ( $5 \mathrm{~min}$ ), then run on $8 \%$ SDS/PAGE and transferred to poly(vinylidene difluoride) membrane. Membranes were blocked (30 min) in 5\% dried milk, then treated with primary $\mathrm{Ab}(1 \mathrm{~h})$, washed 3 times (PBS/0.05\% Tween 20$)$, and incubated $(1 \mathrm{~h})$ with secondary horseradish peroxidase-conjugated $\mathrm{Ab}$. Signal was developed with enhanced chemiluminescence and visualized by autoradiography.

\section{8: Alkaline phosphatase assay:}

Alkaline phosphatase was determined by a modification of the method of Lowry (1955). Chondrocytes were washed with PBS three times. 500 $\mu$ l of ice cold extraction buffer which contains $0.01 \mathrm{M}$ Tris- $\mathrm{HCl}$ was added to the petri dishes and the cells were lysed by freezing in a liquid ethanol-dry-ice bath and thawed at $37^{\circ} \mathrm{C}$ for three times. The cell lysate was centrifuged at $10,000 \mathrm{~g}$ for $20 \mathrm{~min}$ at $4^{\circ} \mathrm{C}$ and cell pellet used to estimate the DNA content while supernatant were removed for alkaline phosphatase activity. Alkaline phosphatase activity was assayed by measuring the release of p-nitrophenol from p-nitrophenylphosphate at $37^{\circ} \mathrm{C}$. The assay mixture $(100 \mu \mathrm{l})$ contains $0.2 \mathrm{M}$ diethanolamine- $\mathrm{HCl}$ ( $\mathrm{pH} 9.8), 1 \mathrm{mM} \mathrm{MgCl} 2$ and $1 \mathrm{mg} / \mathrm{ml}$ p-nitrophenylphosphate. 


\section{9: Statistical Analysis}

All data are expressed as mean \pm SD. The Student's two-tailed unpaired $t$ test was used to determine statistical significance of the difference between the pretreated samples vs untreated or control samples.

\section{Results}

The chondrocytes were pre-treated with varying doses of 5-aza-2' deoxycytidine for $48 \mathrm{~h}$ and then maintained in the normal culture conditions for up to three weeks. The control and pretreated chondrocytes cultures were grown on multiwall culture plates in triplicates. They were released from the ECM by trypsinisation and collagenase digestion and counted on automated coulter counter as well as viable cell count by trypan blue exclusion test. A dose dependent cytotoxic effect of 5-aza dC was observed at Day $7^{\text {th }}$ in culture (Fig 1).

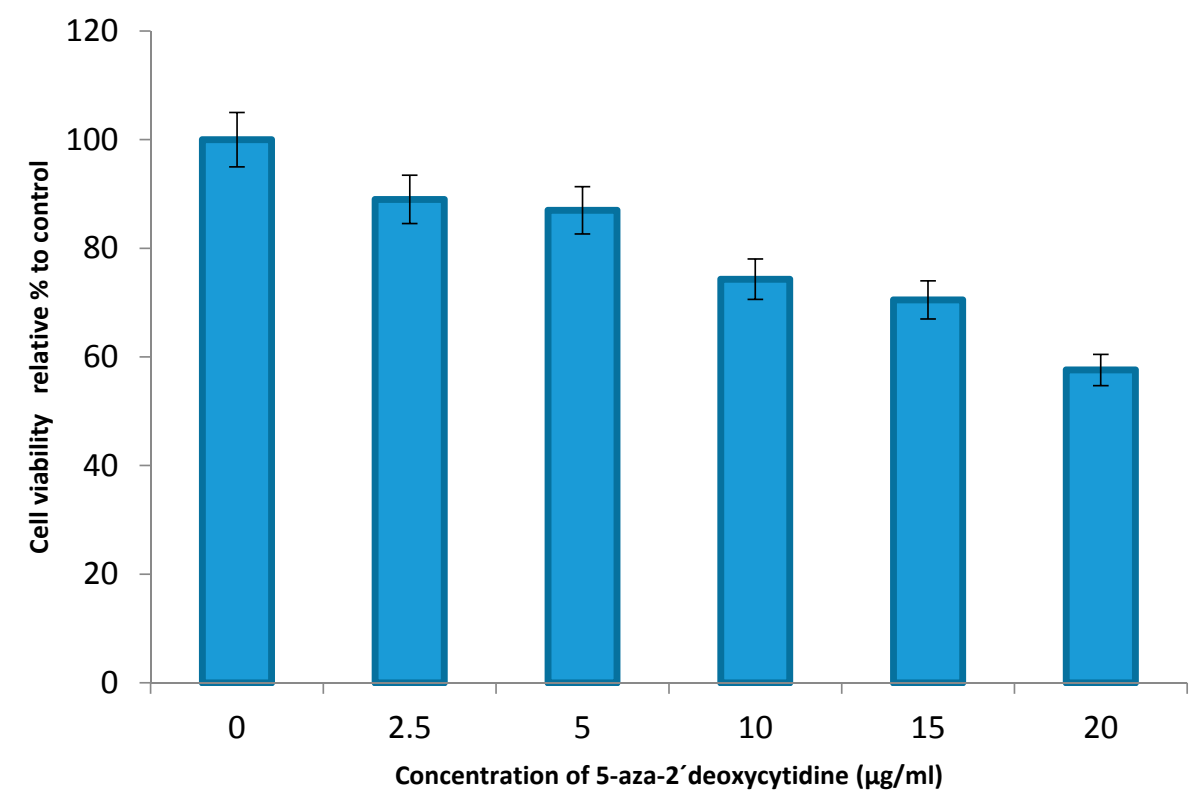

Fig 1: The Chick sternal chondrocytes grown in the absence and presence of varing doses of 5 -azadC for $48 \mathrm{~h}$ and than cultured without any treatments for 7 days. On Day $7^{\text {th }}$ the cells were trysinized briefly and counted on outomated counter as well as viable cell count by trypan blue exclusion dye method and expressed as \% viability relative to control. For each condition three random fields of cells from triplicate wells were counted. Values are normalized by the value in control group. 
The total DNA synthesis was assessed at various doses of 5-aza dC after 72h in culture as described in materials and method section, a dose dependent increase in DNA synthesis on per cell basis was observed (Fig 2A). The maximum incorporation was observed at $15 \mu \mathrm{g} / \mathrm{ml}$ which shows a fivefold increase in DNA synthesis. In other experiments (results not shown) pre-treated cells with $15 \mu \mathrm{g} / \mathrm{ml}$ of 5-aza dC resulted in a two fold increase in DNA content after $7^{\text {th }}$ day in culture as compared to the control cultures.

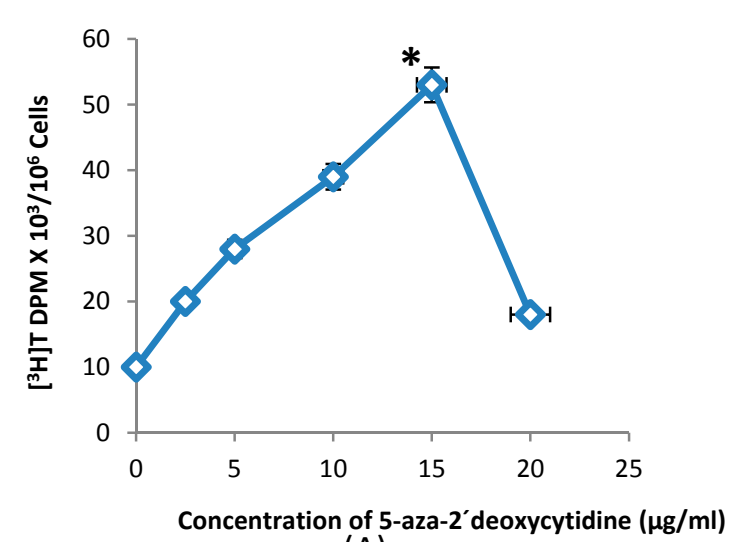

(A)

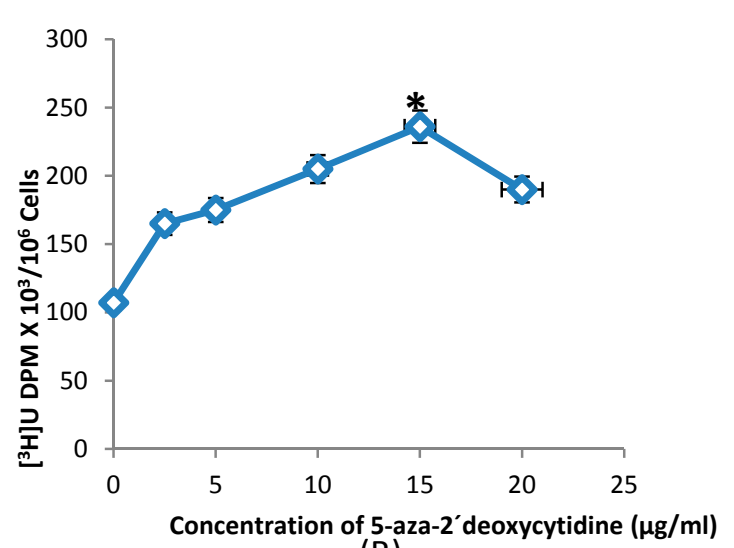

(B)

Fig 2.Dose dependent increase in $\left[{ }^{3} \mathrm{H}\right]$ thymidine and $\left[{ }^{3} \mathrm{H}\right]$ uridine Incorporation:

A: Embryonic Chick sternal Caudal region chondrocytes were grown in the presence of varying doses of 5 azadC for $48 \mathrm{~h}$ in multiwall plates in triplicate followed by a pulse with $\left[{ }^{3} \mathrm{H}\right]$ thymidine for $24 \mathrm{~h}$ in the absence of the treatments. Total [ $\mathrm{H}$ ] thymidine incorporation in the triplicate control and pretreated cultures $( \pm \mathrm{SD})$ were expressed as DPM/106 cells. ${ }^{*} \mathrm{P}<0.0001$ as compared to the control samples.B: Control and pretreated chondrocytes were pulsed with $\left[{ }^{3} \mathrm{H}\right]$ uridine as described in Materials and methods. Total $\left[{ }^{3} \mathrm{H}\right]$ Uridine incorporation into the control and pretreated cultures in triplicates $( \pm \mathrm{SD})$ were expressed as DPM/106 cells. ${ }^{*} \mathrm{P}<0.0001$ as compared to the control samples.

When the total RNA synthesis was measured after $72 \mathrm{~h}$ in culture at various concentrations of

5-aza-2' deoxycytidine, again maximum incorporation of [ $\left.{ }^{3} \mathrm{H}\right]$ Uridine was observed at $15 \mu \mathrm{g} / \mathrm{ml}$.

which exhibited 1.5 fold increases in total RNA synthesis per cell basis when compared to cells without any pre- treatment (Fig 2B). 


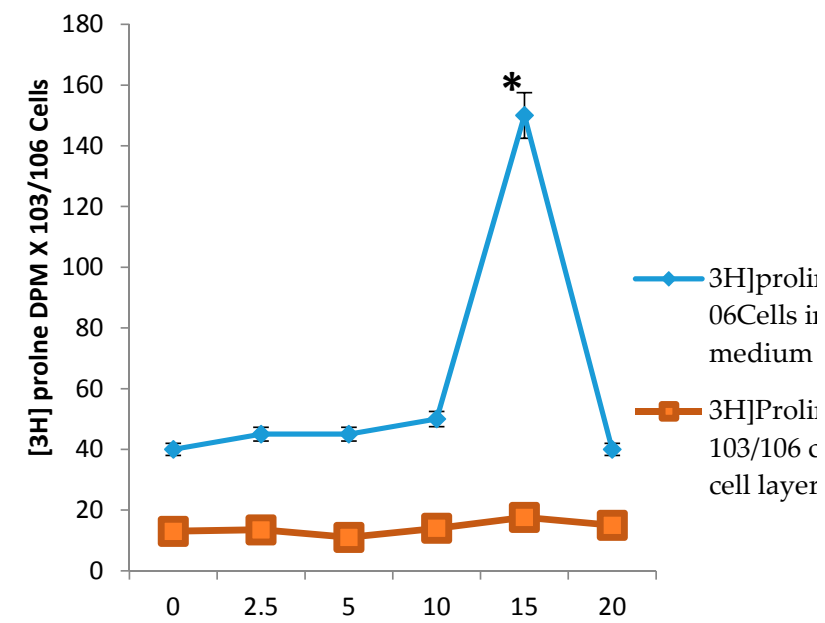

Concentration of 5-aza-2' deoxycytidine $(\mu \mathrm{g} / \mathrm{ml})$

(A)

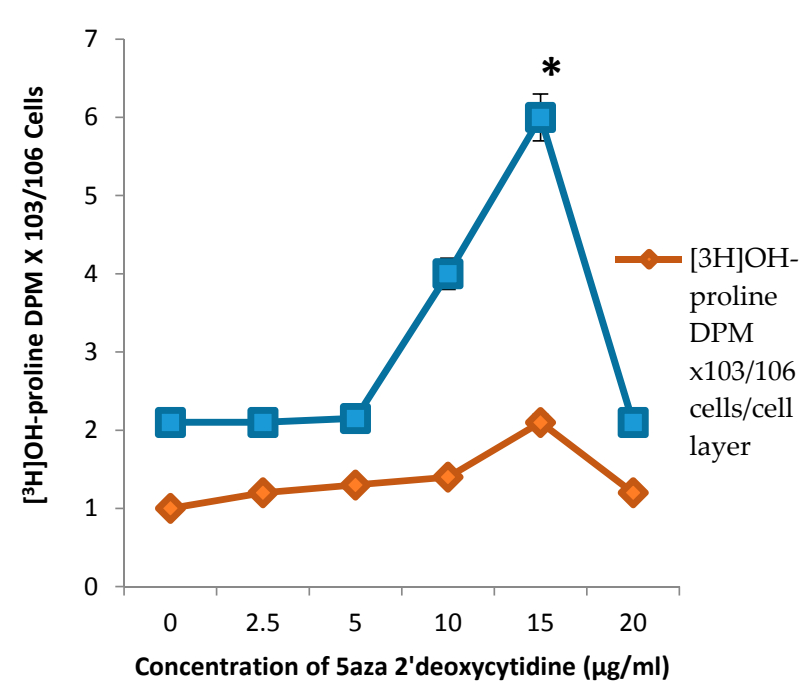

(B)

Fig 3: Dose dependent Increase in $\left[{ }^{3} \mathrm{H}\right]$ proline and $\left[{ }^{3} \mathrm{H}\right]$ hydroxyl-proline incorporation:The control and pretreated cultures were maintained in the normal culture medium as described in the materials and methods section to Day $7^{\text {th }}$, after that they were labeled with $\left[{ }^{3} \mathrm{H}\right]$ proline for $24 \mathrm{~h}$. Medium and Cell/matrix proteins were hydrolyzed with $6 \mathrm{M} \mathrm{HCl}$ after dialysis against running tap water. Hydrolyzed was rotary evaporated and dissolved in $1 \mathrm{M} \mathrm{HCl}$ and counted on scintillation counter. $\left[{ }^{3} \mathrm{H}\right]$ proline incorporation was expressed as DPM $/ 10^{6}$ Cells. For hydroxyproline assay about $1500 \mathrm{cpm}$ was applied onto an amino acid analyzer.A: Incorporation of $\left[{ }^{3} \mathrm{H}\right]$ proline into collagenous and non-collagenous medium and cell lysate proteins in triplicate samples $( \pm \mathrm{SD})$ at day $7^{\text {th }}$ in culture with varying concentration of 5-aza $2^{\prime}$ deoxycytidine. ${ }^{*} \mathrm{P}<0.0001$ when compared to the control samples.B: Incorporation of $\left[{ }^{3} \mathrm{H}\right] \mathrm{OH}$ proline into the collagenous medium and Cell lysate proteins in triplicate samples $( \pm \mathrm{SD})$ at day $7^{\text {th }} \quad$ in culture. ${ }^{*} \mathrm{P}<0.0001$ when compared to the control samples

The influence of 5-aza-2 deoxycytidine on total protein synthesis was also assessed at day $7^{\text {th }}$ by analyzing the incorporation of $\left[{ }^{3} \mathrm{H}\right]$ proline per cell into non diffusible macromolecule. The results showed a dose dependent increase in protein synthesis (Fig 3A). In order to determine $\left[{ }^{3} \mathrm{H}\right]$ proline incorporation into collagenous protein, medium hydro-lysate were subjected to amino acid analyzer in which hydroxyl[ $\left[{ }^{3} \mathrm{H}\right]$ proline was measured and plotted as a function of various concentration of 5-aza dC (Fig 3B). Again maximum incorporation was shown at $15 \mu \mathrm{g} / \mathrm{ml}$ with the rate of synthesis of collagenous protein increasing about four fold at this concentration. Total $\left[{ }^{3} \mathrm{H}\right]$ proline incorporation into the cell layer/matrix also indicated a dose dependent increase in both collagenous and non-collagenous protein synthesis. (Fig 3A, B) 
As $15 \mu \mathrm{g} / \mathrm{ml}$ of 5-aza-2' deoxycytidine was the optimum concentration for chondrocytes proliferation and collagen synthesis, so this concentration was further used to study the gene expression of various collagen types. The biosynthetic profile showed that in the pretreated cultures type $X$ collagen represented $25 \%$ of the total collagen secreted in the medium as compared to the control cultures where Type $\mathrm{X}$ constituted only about $3 \%$ of the total collagen being secreted into the medium. The relative proportion of Type II and Type I collagens were also very different in the control and treated cultures (Fig 4 A, B).

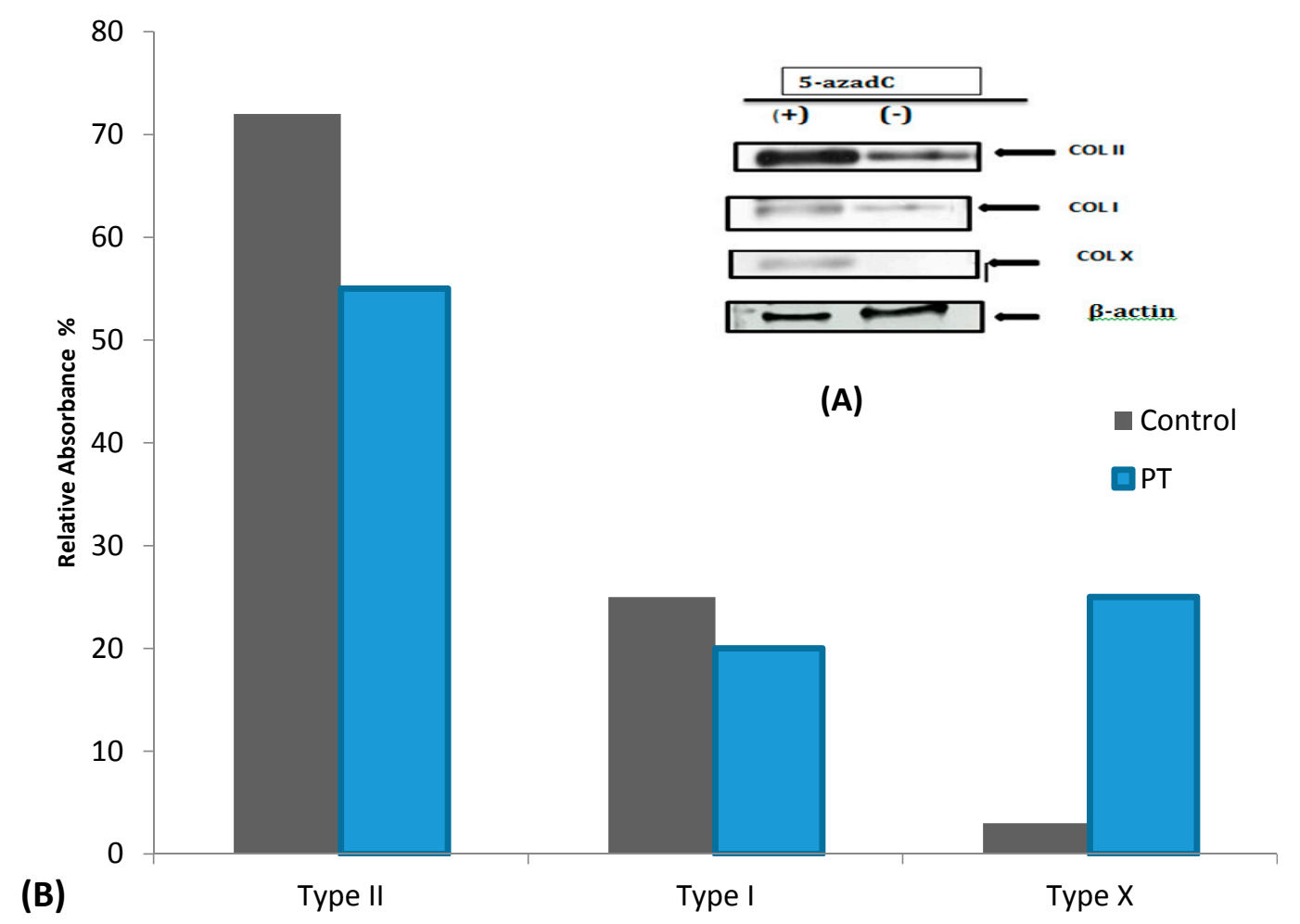

Fig 4: A:Western Blot analysis for Collagen types I, II and X for C (control) and PT (pretreated cells): Medium proteins from 7-day control and pretreated cultures were extracted by $30 \%$ ammonium sulphate precipitation and run on $8 \%$ SDS-PAGE. The proteins were blotted onto nitrocellulose membrane and immunoblotted with antibodies against collagen Type I, Type II, Type $X$ and $\beta$ actin. B: Histogram of the laser densitometry scans of the western blot in fig 3A. Laser densitometry quantification for collagen type II, type I and Type X and beta actin as housekeeping gene, using LKB 2202 ultrascan laser densitometer. The results are expressed as relative absorbance in percentage and the amount of Type II, Type I collagen and type $\mathrm{X}$ collagen were quantitated with respect to these types of collagen secreted into the medium. 
Alkaline phosphatase enzyme activity which is a biomarker of the mineralization process was also

investigated. The caudal region chondrocytes were treated with various concentration of 5-aza dC

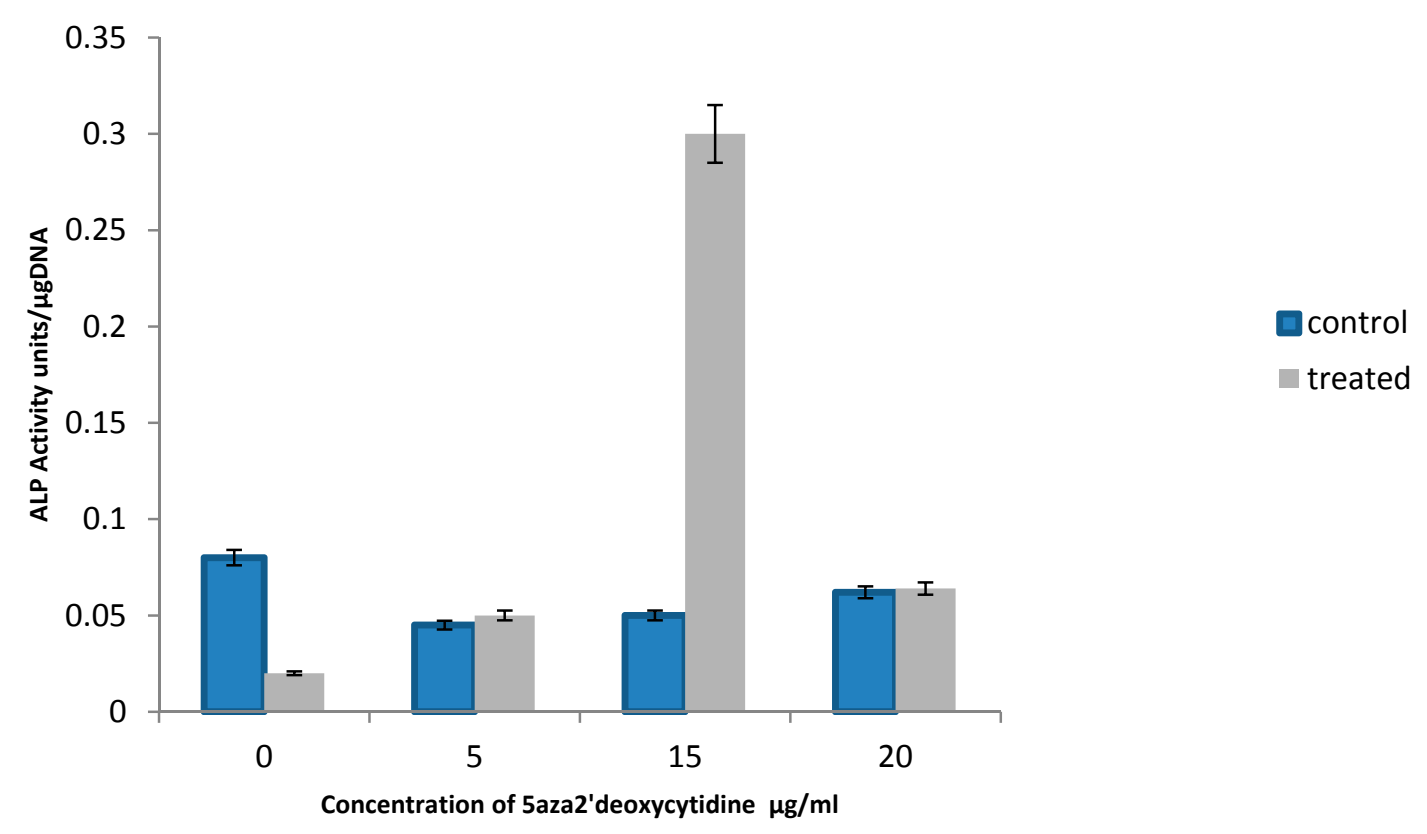

for $48 \mathrm{~h}$ and then maintained in normal culture conditions as described before for up to $14^{\text {th }}$ days.

The amount of the enzyme released into the medium was assessed, which showed a dose dependent increase in alkaline phosphatase activity (Fig $5 \mathrm{~A})$.

\section{Discussion}

The involvement of DNA methylation in controlling the differentiation of stem cells has been reported recently in a number of studies, the most relevant is the pretreatment of bone marrow derived mesenchymal stem cells with 5 aza cytidine resulted in the osteogenic gene expression [15]. The treatment of cultured cells with 5-Azacytidine results in replacement of cytosine bases in genomic DNA with this analogue, which cannot be methylated by methyl transferase and thus perturbs the methylation pattern of cytidine (CpG islands) present in various target gene promoters. Under normal conditions repression of hyper methylated genes primarily occurs via transcription 
factor competition with methyl -CpG binding proteins for binding to regulatory sites in the DNA, thus removing the methylated CpG target with azacytidine treatment facilitates transcription factor access to previously occluded sites in the DNA relieving transcription repression [16, 17].

Since preservation of normal pattern of methylation is crucial for appropriate mammalian development. Azacytidine treatment represents a potent modulator of the developmental process and it has been exploited in a number of different primary culture systems including mouse embryonic fibroblasts [18] and eryhroleukemia cells [19].

In this study the effect of hypomethylating drug 5-aza-2'deoxycytidine (Decitabine) recently approved by FDA to treat myelodysplastic syndrome was investigated on the cultured chondrocytes. Most of the earlier studies had used $15 \mu \mathrm{g} / \mathrm{ml}$ of this drug as the treatment dose [4, 24]. This study investigated the detailed effect of the varying doses of this drug and further emphasized that the optimal concentration of this drug was indeed $15 \mu \mathrm{g} / \mathrm{ml}$.

It is interesting to note that unlike 5-azacytidine, which can intercalate in both DNA and RNA could be effective in inducing differentiation and morphological changes to the cells at any stage of cell cycle and development. 5-aza 2'deoxycytidine has the ability to only intercalate in DNA, so it is most effective at the replicative stage of cells. This replaces normal cytosine and forms irreversible adducts with DMTs, thus inhibiting genome wide methylation [21]. Once the methylation pattern of the growing cells was altered by the treatment of the demethylation drug, growing in its absence would make no difference to the cells as the change in pattern of methylation was conserved and successfully maintained in their daughter cells [22, 23].

This has been demonstrated in this study which showed that the optimum time of treatment was just after plating the primary culture on the culture dishes as the first few cell divisions in the presence of this drug were crucial for the epigenetic imprinting of the cells. After that they were kept in normal culture medium similar to that of control cells.

We observed that there was a significant increase in DNA synthesis as per cell basis in the pretreated cultures as compared to the control. There was also a genome wide enhancement of 
transcription as well as translation as that reflected in overall increase in RNA synthesis and protein synthesis in the pretreated cultures when compared to the control cultures. We found that pretreated of chondrocytes induced the expressions of collagen type $X$ with the subsequent induction of ALP expression. The up-regulation of marker genes of hypertrophy (type X collagen) and mineralization (ALP) of chondrocytes demonstrated that the chondrocytes underwent differentiation in the manner similar to endochondral bone formation which occurs in the growth plate in-vivo. This study further emphasized the need for looking at epigenetic mechanism at molecular levels in detail and explores its significance in various pathological conditions of the bone.

\section{Conclusions}

Cells of a multicellular organism are genetically homogeneous but structurally and functionally heterogeneous owing to the differential expression of genes. Many of these differences in gene expression arise during development and are subsequently retained through mitosis. Over the past few years research was focused on the molecular mechanisms that mediate these epigenetics phenomena. In this study we have investigated the effect of demethylation drug 5aza-dC (methyltransferase inhibitor) in promoting proliferation and differentiation of chondrocytes in culture. Our results showed that pretreatment of chondrocytes in culture could results in upregulation of hypertrophic marker genes, thus initiating the differentiating pathways. The cell culture system described here provides an excellent tool to determine the role of methylation in differentiation and maturation of chondrocytes, as well as it can be exploited to study the role of methylation in gene expression of various types of cells in culture.

Acknowledgments: The author extents their appreciation to the research Centre, King Saud University.

Conflicts of Interest: There is no conflict of interest to declare. 


\section{References}

[1] G.J. Gibson, M.H. Flint, Type X collagen synthesis by chick sternal cartilage and its relationship to endochondral development, J Cell Biol, 101 (1985) 277-284.

[2] P. LuValle, M. Hayashi, B.R. Olsen, Transcriptional regulation of type $X$ collagen during chondrocyte maturation, Dev Biol, 133 (1989) 613-616.

[3] A.M. Reginato, J.W. Lash, S.A. Jimenez, Biosynthetic expression of type $X$ collagen in embryonic chick sternum cartilage during development, J Biol Chem, 261 (1986) 2897-2904.

[4] J.T. Thomas, S. Ayad, M.E. Grant, Cartilage collagens: strategies for the study of their organisation and expression in the extracellular matrix, Ann Rheum Dis, 53 (1994) 488-496.

[5] P. LuValle, K. Daniels, E.D. Hay, B.R. Olsen, Type X collagen is transcriptionally activated and specifically localized during sternal cartilage maturation, Matrix, 12 (1992) 404-413.

[6] T.M. Schmid, T.F. Linsenmayer, Immunohistochemical localization of short chain cartilage collagen (type X) in avian tissues, J Cell Biol, 100 (1985) 598-605.

[7] P. Castagnola, B. Dozin, G. Moro, R. Cancedda, Changes in the expression of collagen genes show two stages in chondrocyte differentiation in vitro, J Cell Biol, 106 (1988) 461-467.

[8] K. von der Mark, T. Kirsch, A. Nerlich, A. Kuss, G. Weseloh, K. Gluckert, H. Stoss, Type X collagen synthesis in human osteoarthritic cartilage. Indication of chondrocyte hypertrophy, Arthritis Rheum, 35 (1992) 806-811.

[9] K. von der Mark, S. Frischholz, T. Aigner, F. Beier, J. Belke, S. Erdmann, H. Burkhardt, Upregulation of type $X$ collagen expression in osteoarthritic cartilage, Acta Orthop Scand Suppl, 266 (1995) 125-129.

[10] P. Zimmermann, S. Boeuf, A. Dickhut, S. Boehmer, S. Olek, W. Richter, Correlation of COL10A1 induction during chondrogenesis of mesenchymal stem cells with demethylation of two CpG sites in the COL10A1 promoter, Arthritis Rheum, 58 (2008) 2743-2753.

[11] J. Buckland, Osteoarthritis: Epigenetic clues into the molecular basis of OA, Nature Reviews Rheumatology, 10 (2014) 383-383.

[12] M. D'Angelo, M. Pacifici, Articular chondrocytes produce factors that inhibit maturation of sternal chondrocytes in serum-free agarose cultures: a TGF-beta independent process, J Bone Miner Res, 12 (1997) 1368-1377.

[13] T. Sorger, R.J. Germinario, A direct solubilization procedure for the determination of DNA and protein in cultured fibroblast monolayers, Anal Biochem, 131 (1983) 254-256.

[14] K. Juva, D.J. Prockop, Modified procedure for the assay of H-3-or C-14-labeled hydroxyproline, Anal Biochem, 15 (1966) 77-83.

[15] G.S. Zhou, X.L. Zhang, J.P. Wu, R.P. Zhang, L.X. Xiang, L.C. Dai, J.Z. Shao, 5-Azacytidine facilitates osteogenic gene expression and differentiation of mesenchymal stem cells by alteration in DNA methylation, Cytotechnology, (2009).

[16] H.H. Ng, Y. Zhang, B. Hendrich, C.A. Johnson, B.M. Turner, H. Erdjument-Bromage, P. Tempst, D. Reinberg, A. Bird, MBD2 is a transcriptional repressor belonging to the MeCP1 histone deacetylase complex, Nat Genet, 23 (1999) 58-61.

[17] P.A. Wade, Methyl CpG-binding proteins and transcriptional repression, Bioessays, 23 (2001) 1131-1137.

[18] P.G. Constantinides, S.M. Taylor, P.A. Jones, Phenotypic conversion of cultured mouse embryo cells by aza pyrimidine nucleosides, Dev Biol, 66 (1978) 57-71. 
[19] F. Creusot, G. Acs, J.K. Christman, Inhibition of DNA methyltransferase and induction of Friend erythroleukemia cell differentiation by 5-azacytidine and 5-aza-2'-deoxycytidine, J Biol Chem, 257 (1982) 2041-2048.

[20] J.K. Christman, 5-Azacytidine and 5-aza-2'-deoxycytidine as inhibitors of DNA methylation: mechanistic studies and their implications for cancer therapy, Oncogene, 21 (2002) 5483-5495. [21] T. Chen, Y. Ueda, J.E. Dodge, Z. Wang, E. Li, Establishment and maintenance of genomic methylation patterns in mouse embryonic stem cells by Dnmt3a and Dnmt3b, Mol Cell Biol, 23 (2003) 5594-5605.

[22] A. Bird, DNA methylation patterns and epigenetic memory, Genes Dev, 16 (2002) 6-21.

(C) 2016 by the authors; licensee Preprints, Basel, Switzerland. This article is an open access article distributed under the terms and conditions of the Creative Commons by Attribution (CC-BY) license (http://creativecommons.org/licenses/by/4.0/). 